\title{
Comparison of the Effects of Soy Protein and Whey Protein Supplementation during Exercise: a Systematic Review
}

\section{Comparação dos Efeitos da Suplementação de Whey Protein e Proteína de Soja Durante o Exercício: uma Revisão Sistemática}

\author{
Suelen Maiara Medeiros da Silva*a; Bárbara Cristovão Carminatia; Valfredo de Almeida Santos Junior ${ }^{\text {b; }}$ \\ Pablo Christiano Barboza Lollo \\ aUniversidade Federal da Grande Dourados, Programa de Pos-Graduação Stricto Sensu em Ciências Saúde. MS, Brasil. \\ bUniversidade de Campinas, Programa de Pos-Graduação Stricto Sensu em Alimentos e Nutrição. SP, Brasil. \\ *E-mail: su.medei.ros@hotmail.com \\ Recebido em: 18/03/2019; Aprovado em: 03/07/2019
}

\begin{abstract}
The interest of the supplementation market for the soy protein consumption to optimize physical and metabolic performance after exercise is increasing. However, evidence suggests that the soy protein ingestion has lower anabolic properties when compared with whey protein. The purpose of this systematic review was to compare the effects of whey protein and soy protein supplementation on the muscle functions maintenance after exercise. This review was performed using the Preferred Reporting Items for Systematic Reviews and Meta-Analyses (PRISMA). Articles were searched for in the Pubmed database and included studies comparing the effects of soy protein and whey protein consumption on protein synthesis, lean mass gain and oxidative stress reduction in response to endurance or resistance training. Thirteen trials were included in this review. The results showed that the whey protein consumption is superior to that of soy protein with respect to protein synthesis and lean mass gain, but soy protein showed superior results in reducing oxidative stress. Future research comparing both soy and whey protein are needed to define protein source to be used in nutritional interventions to protein synthesis, lean mass gain and oxidative stress in different populations.
\end{abstract}

Keywords: Soybean Proteins. Milk Proteins. Protein Biosynthesis. Hypertrophy.

\section{Resumo}

O interesse do mercado de suplementação pelo consumo de proteína de soja para otimizar o desempenho fisico e metabólico após o exercício está aumentando. No entanto, evidências sugerem que a ingestão da proteina de soja tem propriedades anabólicas mais baixas quando comparada à proteina do soro do leite. O objetivo desta revisão sistemática foi comparar os efeitos da suplementação com whey protein e proteina de soja na manutenção das funções musculares após o exercício. Esta revisão foi realizada usando os Itens de Relatório Preferidos para Revisões Sistemáticas e Meta-Análises (PRISMA). Os artigos foram pesquisados na base de dados Pubmed e incluíram estudos comparando os efeitos da proteína de soja e do consumo de proteínas do soro na síntese protéica, ganho de massa magra e redução do estresse oxidativo em resposta ao treinamento de resistência ou resistência. Treze ensaios foram incluídos nesta revisão. Os resultados mostraram que o consumo de proteína de soro é superior ao da proteína de soja em relação à síntese protéica e ao ganho de massa magra, mas a proteína de soja apresentou resultados superiores na redução do estresse oxidativo. Pesquisas futuras comparando a soja e a proteina do soro do leite são necessárias para definir a fonte protéica a ser usada em intervenções nutricionais para a síntese protéica, ganho de massa magra e estresse oxidativo em diferentes populações.

Palavras-chave: Proteinas de Soja. Proteínas do Leite. Biossíntese de Proteínas. Hipertrofia.

\section{Introduction}

Potentiating muscle recovery after exercise is essential to maximize muscle adaptations. The literature indicates the key role of protein intake in the metabolic functions balance after exercise $^{1}$. Protein-based supplements are often used for the rapid delivery of amino acids into the systemic circulation, facilitating protein anabolism in the muscle ${ }^{2}$. The intake of soy protein and whey protein may reduce the oxidative stress caused by intense exercise ${ }^{3}$ and reduce the muscle proteins catabolism, which aids in hypertrophic gains ${ }^{4}$.

The use of soy protein and whey protein supplementation stimulates and maintains muscle growth and strength. Whey protein is used by athletes for muscle recovery and hypertrophy ${ }^{5}$, and the intake of whey protein after exercise was shown to induce hyperaminoacidemia, Mammalian target of rapamycin (mTOR) signaling and muscle protein synthesis ${ }^{6}$ as well as having an antioxidant effect ${ }^{7}$ and maintaining high levels of hepatic glycogen. Soy protein combined with strength training stimulates muscle protein synthesis (MPS) ${ }^{8,9}$, and it also contains antioxidants and may decrease the deleterious effects of exercise ${ }^{10}$. The purpose of this systematic review was to compare the effects of whey protein and soy protein supplementation on the muscle functions maintenance after exercise.

\section{Development}

\subsection{Methodology}

This systematic review was carried out using explicit 
methods that allowed the selection of articles that analyzed the use of whey protein and soy protein supplementation in physical exercise. This systematic review was performed using The Preferred Reporting Items for Systematic Reviews and Meta-Analyses (PRISMA).

The articles research was based on PubMed database until February of 2018. In this search for articles the terms used for soy protein were: "soy", "soy protein", "soy proteins", "soybean", "soy bean" and "soybean protein", and the search was carried out using the "OR" operator between the terms. The terms used for whey protein were: "whey", "whey protein", "milk protein" and "milk serum protein", and the search was again carried out using the "OR" operator between the terms. The terms used for exercise: "physical fitness", "physical performance", "physical exercise", "exercise", "exercise training", "physical training", "exercise program", "exercise performance", "resistance training" and "resistance exercise". The search was carried out using the "OR" operator, between the terms. The combination of the terms related to soy protein, whey protein and exercise was carried out using the "AND" operator.

The included studies were English language, randomized, double-blinded, placebo-controlled trials investigating the effects of soy and whey protein supplementation on measures of protein synthesis, lean mass gain and oxidative stress reduction following exercise. In the initial search for the selected terms, 181 potential articles were identified for inclusion in the review. 131 were excluded because they did not contain the combination of terms in the title and abstract. 39 studies were selected which participated of the inclusion and exclusion criteria. Frase: Foram selecionados 39 estudos que participaram dos critérios de inclusão e exclusão.
The exclusion criteria were applied and the following studies were excluded: a) reviews; b) those focusing on research about hormonal changes; c) diseases; d) hepatic glycogen levels e) those that did not directly compare the effects of soy protein and whey protein supplementation on physical exercise. Thirteen trials were included in this review. The study selection diagram and the selection steps are shown in Figure 1.

Figure 1 - Diagram of selected studies.

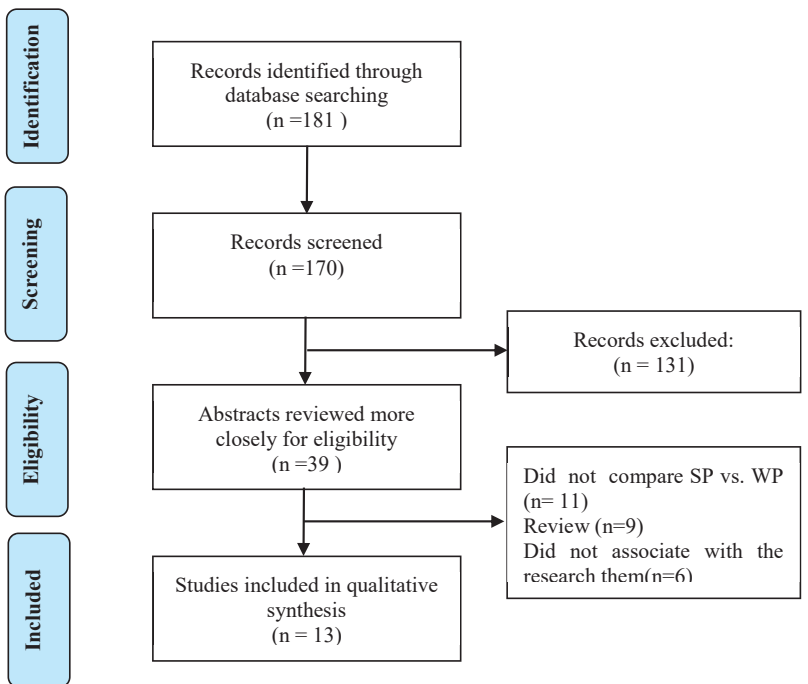

Source: The authors.

\subsection{Findings}

Six studies investigated the effects of soy and whey protein supplementation on the lean mass gain after resistance-trained (Table 1). Five studies investigated the effects of soy and whey protein supplementation on the muscle protein synthesis after resistance and endurance exercise (Table 2).

Table 1 - Comparison between the effects of the intake of WP and SP on lean body mass gain after resistance exercise

\begin{tabular}{|c|c|c|c|c|c|}
\hline Authors & Sample & Supplementation/day & Exercise & Methods & Main Findings \\
\hline Aristizabal et al. ${ }^{16}$ & $\begin{array}{l}61 \text { men and women } \\
(18-35 \text { years })\end{array}$ & $\sim 0.3 \mathrm{~g} / \mathrm{kg}$ WP or SP & $\begin{array}{l}\text { resistance } \\
\text { exercise for } 36 \\
\text { weeks }\end{array}$ & DXA & $\downarrow$ lean body mass \\
\hline Volek et al. ${ }^{15}$ & $\begin{array}{l}63 \text { men and women } \\
(18-35 \text { years })\end{array}$ & $\sim 0.3 \mathrm{~g} / \mathrm{kg}$ WP or SP & $\begin{array}{l}\text { resistance } \\
\text { exercise for } 36 \\
\text { weeks }\end{array}$ & DXA & $\downarrow$ lean body mass \\
\hline Mobley et al. ${ }^{14}$ & 75 men (20-22 years) & $\begin{array}{l}\sim 0.35 \mathrm{~g} / \mathrm{kg} \mathrm{WP} \\
\sim 0.5 \mathrm{~g} / \mathrm{kg} \mathrm{SP}\end{array}$ & $\begin{array}{l}\text { resistance } \\
\text { exercise for } 12 \\
\text { weeks }\end{array}$ & DXA & $=$ lean body mass \\
\hline Kalman et al. ${ }^{13}$ & $\begin{array}{l}20 \text { men and women } \\
(18-40 \text { years })\end{array}$ & $\sim 0,6 \mathrm{~g} / \mathrm{kg} \mathrm{WP}$ or SP & $\begin{array}{l}\text { resistance } \\
\text { exercise for } 12 \\
\text { weeks }\end{array}$ & DXA & $=$ lean body mass \\
\hline Candow et al. ${ }^{11}$ & $\begin{array}{l}27 \text { men and women } \\
(18-35 \text { years })\end{array}$ & $1,2 \mathrm{~g} / \mathrm{kg} \mathrm{WP}$ or SP & $\begin{array}{l}\text { resistance } \\
\text { exercise for } 6 \\
\text { weeks }\end{array}$ & DXA & $=$ lean body mass \\
\hline Brown et al ${ }^{12}$ & $\begin{array}{l}27 \text { men }(18-25 \\
\text { years })\end{array}$ & $\sim 0,4 \mathrm{~g} / \mathrm{kg} \mathrm{WP}$ or SP & $\begin{array}{l}\text { resistance } \\
\text { exercise for } 9 \\
\text { weeks }\end{array}$ & HW & $=$ lean body mass \\
\hline
\end{tabular}


Table 2 - Comparison between the effects of the intake of WP and SP in muscle protein synthesis during exercise

\begin{tabular}{|c|c|c|c|c|c|}
\hline Authors & Sample & Exercise & Supplementation & Methods & Main Findings \\
\hline Kanda et al. ${ }^{20}$ & 190 Rats & $\begin{array}{l}\text { swimming ( } 2 \\
\text { hours) }\end{array}$ & $3.1 \mathrm{~g} / \mathrm{kg} \mathrm{WP}$ or SP & FSR & $\begin{array}{l}\downarrow \text { FSR } \\
=\text { insulin concentration } \\
\downarrow \text { leucinemia } \\
\downarrow \text { BCAA }\end{array}$ \\
\hline \multirow{2}{*}{ Yang et al. ${ }^{17}$} & \multirow{2}{*}{$\begin{array}{c}30 \text { men } \\
\text { (66-76 years) }\end{array}$} & \multirow{2}{*}{ resistance exercise } & \multirow{2}{*}{$\begin{array}{c}\sim 0.25 \mathrm{~g} / \mathrm{kg} \text { and } \\
\sim 0.5 \mathrm{~g} / \mathrm{kg} \mathrm{WP} \text { or SP }\end{array}$} & \multirow{2}{*}{ FSR } & $\begin{array}{l}\sim 0.25 \mathrm{~g} / \mathrm{kg} \\
\downarrow \text { FSR } \\
=\text { insulin concentration } \\
\downarrow \text { leucinemia } \\
=\text { leucine oxidation, BCAA, } \\
\text { EAA, TAA }\end{array}$ \\
\hline & & & & & $\begin{array}{l}\sim 0.5 \mathrm{~g} / \mathrm{kg} \\
\downarrow \mathrm{FSR} \\
=\text { insulin concentration } \\
\downarrow \text { leucinemia } \\
\uparrow \text { leucine oxidation } \\
\downarrow \text { BCAA, EAA, TAA } \\
\end{array}$ \\
\hline Tang et al. ${ }^{19}$ & $\begin{array}{c}18 \text { men } \\
(19-25 \text { years })\end{array}$ & resistance exercise & $\begin{array}{c}\sim 0.3 \mathrm{~g} / \mathrm{kg} \mathrm{WP} \text { or } \\
\mathrm{SP}\end{array}$ & FSR & $\begin{array}{l}\downarrow \text { FSR } \\
=\text { insulin concentration } \\
\downarrow \text { leucinemia } \\
\downarrow \text { EAA }\end{array}$ \\
\hline Anthony et al. ${ }^{21}$ & 30 Rats & Running (2 hours) & $\begin{array}{c}\sim 0.9 \mathrm{~g} / \mathrm{kg} \text { WP or } \\
\mathrm{SP}\end{array}$ & FSR & $\begin{array}{l}=\text { FSR } \\
\downarrow \text { insulin concentration } \\
\downarrow \text { leucinemia } \\
\downarrow \text { phosphorylation of mTOR }\end{array}$ \\
\hline Mitchell et al. ${ }^{18}$ & $\begin{array}{c}13 \text { men } \\
(60-75 \text { years })\end{array}$ & resistance exercise & $\sim 0.5 \mathrm{~g} / \mathrm{kg}$ WP or SP & WB & $\begin{array}{l}=\text { phosphorylation of } \\
\text { P70S6K }\end{array}$ \\
\hline
\end{tabular}

Subtitle: WP: Whey protein; SP: Soy protein; FSR: fractional rates of protein synthesis; WB: Western Blotting; BCAA: branched- chain amino acids; EAA: essential amino acids; TAA: total of all amino acids; =: no significant differences (SP vs. WP); $\uparrow:$ significantly greater (SP vs. WP); $\downarrow$ : significantly lower (SP vs. WP);

Source: Research data.

Three studies investigated the effects of soy and whey protein supplementation on oxidative stress after resistance exercise (Table 3). These studies are compiled with details in Tables 1-3 and discussed in this review.

Table 3- Comparison between the effects of the intake of WP and SP on oxidative stress after resistance exercise

\begin{tabular}{|c|c|c|c|c|c|c|l|}
\hline Authors & N & Sex & Age & Training & Supplementation & Methods & \multicolumn{1}{|c|}{ Results } \\
\hline Box et al. ${ }^{22}$ & 18 & F & $18-25$ & 4 weeks & $33 \mathrm{~g}$ & $\begin{array}{l}\uparrow^{*} \text { TAS } \\
\downarrow^{*} \text { PLP values } \\
=^{\#} \text { TAS } \\
=^{*} \text { PLP }\end{array}$ \\
\hline Hill et al. ${ }^{23}$ & 18 & $\mathrm{M}$ & $18-25$ & 4 weeks & $40 \mathrm{~g}$ & PLP & $\begin{array}{l}\downarrow^{*} \text { PLP values } \\
=^{\#} \text { PLP }\end{array}$ \\
\hline $\begin{array}{c}\text { Brown et } \\
\text { al. }{ }^{12}\end{array}$ & 27 & F/M & $19-25$ & 9 weeks & $39 \mathrm{~g}$ & TAS & $\begin{array}{l}=^{*} \text { TAS } \\
\downarrow^{\#} \text { TAS }\end{array}$ \\
\hline
\end{tabular}

Subtitle: WP: Whey protein; SP: Soy protein; TAS: Total antioxidant status; PLP: Plasma lipid peroxides. *: SP vs. Pre exercise; \#: WP vs. Pre exercise. Source: Research data.

\subsection{Whey protein vs. soy protein in increasing lean muscle mass}

Six studies investigated the effects of soy and whey protein supplementations on the lean mass gain after resistancetrained in young people. Four of the six studies found a lean mass gain after 6-12 weeks of training ${ }^{11-13}$. Candow et al. ${ }^{11}$ supplemented $0.4 \mathrm{~g} / \mathrm{kg}$ WP and SP, 3 times/ day for 6 weeks. Brown et al. ${ }^{12}$ supplemented with $\sim 0.13 \mathrm{~g} / \mathrm{kg}$ WP and SP, 3 times/ day for 9 weeks. Kalman et al.13 supplemented with $\sim 0.3 \mathrm{~g} / \mathrm{kg}$ WP and SP, 2 times/ day for 12 weeks. Mobley et al. ${ }^{14}$ supplemented with $\sim 0.4 \mathrm{~g} / \mathrm{kg}$ WP and supplemented with $\sim 0.5 \mathrm{~g} / \mathrm{kg}$ SP for 12 weeks. There were no significant differences in the increases in lean mass between the groups supplemented with WP and SP. Two of the six studies found a lean mass gain after 36 weeks of training ${ }^{15,16}$. Volek et al. ${ }^{15}$ supplemented with $\sim 0.3 \mathrm{~g} / \mathrm{kg}$ WP and SP, per day for 36 weeks. Aristizabal et al. ${ }^{16}$ supplemented with $\sim 0.3 \mathrm{~g} / \mathrm{kg}$ WP and SP, per day for 36 weeks. They observed more significant increases in lean mass for WP than SP. Additional studies are required to determine the difference between SP and WP in increasing lean mass.

\subsection{Whey protein vs. soy protein in muscle protein synthesis}

Supplementation with whey protein is superior to that 
with soy protein for muscle protein synthesis (MPS). Three experiments compared the effect of WP and SP intake on muscle protein synthesis (MPS), after resistance exercise in humans. Yang et al. ${ }^{17}$ supplemented elderly individuals with $\sim 0.25 \mathrm{~g} /$ $\mathrm{kg}$ and $\sim 0.5 \mathrm{~g} / \mathrm{kg}$ of WP and SP. The fractional synthetic rates (FSR) of myofibrillar proteins were calculated. They observed more significant increases in the ability to stimulate protein synthesis in elderly individuals supplemented with WP than in those supplemented with SP in both doses, $1 \mathrm{~h}$ after exercise. Mitchell et al. ${ }^{18}$ supplemented elderly individuals with $\sim 0.5 \mathrm{~g} /$ $\mathrm{kg}$ of WP and SP. It was observed that WP and SP stimulated muscle protein synthesis via p70S6K phosphorylation to a similar degree, $2 \mathrm{~h}$ after exercise. Tang et al. ${ }^{19}$ supplemented 18 young subjects with $\sim 0.3 \mathrm{~g} / \mathrm{kg}$ of WP and SP. The fractional synthetic rates (FSR) of myofibrillar proteins were calculated. It was showed that WP stimulated MPS to a greater degree than SP after resistance exercise.

Two of the five studies compared muscle protein synthesis after 2 hrs of endurance exercise in rats. Kanda et al. ${ }^{20}$ used supplementation of $3.1 \mathrm{~g} / \mathrm{kg}$ of WP and SP. The fractional synthetic rates (FSR) of myofibrillar proteins were calculated. They found that SP induced less MPS than WP 60 min after ingestion. Anthony et al. ${ }^{21}$ used supplementation of $\sim 0.9 \mathrm{~g} / \mathrm{kg}$ of whey or soy protein in a high-carbohydrate diet for rats that took part in a $2 \mathrm{~h}$-endurance exercise session. The results were similar for the induction of muscle protein synthesis $1 \mathrm{~h}$ after consumption of WP and SP, but mTOR phosphorylation was higher in the group that consumed WP than in the one that consumed SP.

Plasma insulin concentration was similar for WP and $\mathrm{SP}^{17,19,20}$ but one study observed that plasma insulin concentration was higher following WP as compared to SP $1 \mathrm{~h}$ post-drink $^{21}$. Higher amplitudes in blood leucinemia were achieved following WP as compared to $\mathrm{SP}^{17,19-21}$. WP produced significantly higher blood amino acids levels compared with $\mathrm{SP}^{17,19,20}$. SP caused a significant increase in leucine oxidation ${ }^{17}$.

\subsection{Whey protein vs. soy protein in the oxidative stress parameters}

Soy protein reduces oxidative stress more than whey protein. Three studies evaluated the effects of WP and SP supplementation on the oxidative stress caused by resistance exercise in young subjects after 4-9 weeks of resistance training. The results indicated that SP was superior to WP in reducing oxidative stress. Box, Hill and DiSilvestro ${ }^{22}$ applied strength training and supplemented with SP or WP 40g/day for 4 weeks. Soy protein increased the total antioxidants concentration and prevented increased blood CK activity. In contrast, WP significantly increased serum lipid peroxide values when compared to pre-exercise values. Hill et al. ${ }^{23}$ supplemented with $40 \mathrm{~g}$ /day of SP or WP for 4 weeks and showed that SP significantly reduced the serum values of lipid peroxide after resistance exercise. Brown et al. ${ }^{12}$ supplemented with $33 \mathrm{~g} /$ day for 9 weeks and found that SP maintained the antioxidant status in the plasma, whereas the consumption of WP significantly decreased the antioxidant status. However, further research is needed to confirm these findings.

\subsection{Discussion}

Regular resistance exercise promotes progressive physiological muscle adaptation. Each exercise session stimulates specific signaling pathways that regulate transcriptional and translational activities in the cell ${ }^{24}$. To achieve lean mass gain, muscle protein synthesis must be greater than muscle protein degradation, resulting in a positive protein balance ${ }^{25}$. Chronic adaptations come from the accumulation of acute effects and are sustained by the regulation of muscle protein synthesis ${ }^{26}$. Supplementation with WP and SP may accentuate these adaptations and promote an increased muscle cross-section, known as muscle hypertrophy. However, the ingestion of soy protein results in lower postprandial MPS rates than the ingestion of whey protein does, results in a lower skeletal muscle hypertrophy when performed chronically.

The supplementation of WP and SP stimulated increases in lean mass to a similar degree after 6-12 weeks, but after 36 weeks of resistance training WP showed superior results in gaining muscle mass than supplementation with soy protein. The supplementation of soy and whey protein after exercise, results in a positive nitrogen balance, stimulating increases in lean mass, however, the WP has better ability to support the muscle protein accretion. In theory, soy and whey protein stimulated the muscular adaptive responses after resistance exercise, promoting, on a long term basis, muscle remodeling, but the soy protein ingestion results in lower stimulation of the skeletal muscle hypertrophy compared with the whey protein. The studies that verified the consumption of whey protein and soy protein on the gain in muscle mass are characterized in Table 1.

Postprandial MPS measurements are used to verify the maintenance or increase of skeletal muscle mass. Changes in MPS are not a quantitative estimate of skeletal muscle remodeling, but indicate hypertrophy when performed chronically ${ }^{27}$. What is known is that mTORC1 activation enhances the MPS. It was verified that increase in MPS activates the protein kinases such as the ribosomal protein of 70-kDa S6 kinase 1 (p70S6K1) and 4E-binding protein-1 (4EBP1) promoting ribosomal binding to mRNA initiating the protein synthesis ${ }^{28}$. In this review, the articles showed that both WP and SP increased MPS, mTOR and p70S6K phosphorylation, but that supplementation with WP obtained better results than SP in both young and elderly population ${ }^{17,18}$. Elderly people are less sensitive to the anabolic effects of diet and exercise. Kumar et al. ${ }^{29}$ associated the reduced effects of resistance exercise on muscle protein synthesis in the elderly with the inability to completely activate mTOR. However, studies showed that WP was superior to SP in protein synthesis 
in humans.

WP induced increase in insulin levels compared to $\mathrm{SP}^{17,21}$. The increase of insulin secretion after exercise,increases the mTOR activity in the muscle ${ }^{30}$. F However, two studies showed no significant difference in plasma insulin levels between SP and WP. Therefore, further studies are required to compare the effects of SP and WP in insulin secretion.

Soy protein contains fewer EAAs than WP. The ingestion of an "unbalanced" AAs profile results in less free AA concentrations in the systemic circulation to support the postprandial increase in MPS ${ }^{31}$. Protein supplementation with whey protein and soy protein increases the circulating amino acids, making the protein balance positive. Tang and Phillips ${ }^{32}$ found that WP and SP supplementation may increase muscle protein synthesis, but that whey protein was superior to soy protein, since the amino acids contained in this protein were available in larger quantities in the bloodstream, facilitating absorption by the muscle cell. Some articles included in this review found a significantly higher increase in the concentration of AAs after the WP consumption than after the SP consumption ${ }^{19-21}$.

Leucine is an important essential amino acid responsible for the increase in MPS. It is known that BCAAs (branched chain amino acids), particularly leucine, have an important role as metabolic regulators of MPS ${ }^{33}$, activating mRNA translation from the rapamycin target $(\mathrm{mTOR})^{34}$. Lollo et al. ${ }^{35}$ stated that leucine was an important amino acid in the mTOR activation and $\mathrm{p} 70 \mathrm{~S} 6 \mathrm{~K}$ pathways. The leucine content of whey protein is higher than that of soy protein (12\% in WP and $8 \%$ in SP) ${ }^{17}$. The results indicated that WP elevated the plasma leucine levels significantly more than $\mathrm{SP}^{20,21}$ hence the amount of leucine present in WP partially explains its superior effect on MPS.

The protein digestion rate and absorption kinetics of the ingested protein source after the exercise are important for modulating postprandial MPS. Rapidly digested proteins support increased rates of MPS. WP and SP are relatively rapidly digested proteins ${ }^{36}$. However, the SP ingestion results in higher AAs oxidation rates than WP ingestion does ${ }^{17}$. This suggests that the AAs from SP are directed toward the deamination pathways. Increasing the concentration of amino acids in the bloodstream may potentiate the protein synthesis process ${ }^{37}$. Thus, Soy protein-derived AAs were less available to stimulate MPS when compared with the whey protein-derived AAs. The results suggest that the SP support to less extent MPS than WP due to differences in digestion and absorption kinetics. Further studies comparing the two proteins are needed to elucidate the potentiation of the initiation of protein synthesis and translation.

An increase in oxidative stress after intense exercise is associated with decreased physical performance, muscle fatigue and muscle damage ${ }^{12}$, and an increase in lipid peroxide values indicates oxidative stress. The articles included in this review suggest that soy protein may promote an antioxidant function during resistance exercise, possibly by the activation of antioxidant enzymes. Soy protein contains antioxidant enzymes such as isoflavones ${ }^{38}$ and research has suggested that the antioxidant action of isoflavones can eliminate free radicals, increasing the antioxidant enzymes expression, and inhibiting lipid peroxidation ${ }^{39}$ and DNA susceptibility to oxidative stress ${ }^{40,41}$. The studies indicated that SP supplementation reduced oxidative stress after resistance training more than WP.

\section{Conclusion}

Physical activity and protein ingestion has been shown to sensitize skeletal muscle tissue to the anabolic properties. Only a few studies have compared the muscle protein synthesis, lean mass gain and oxidative stress response to the ingestion of soy protein vs. whey protein. The evidence suggests that supplemental doses of soy protein may increase the antioxidant defenses, inhibit lipid peroxidation and reduce oxidative stress. The review of the articles indicated that supplementation with WP stimulated the initiation of muscle protein synthesis and translation to a greater degree when compared to supplementation with soy protein. Therefore, soy protein intake was demonstrated to result in lower lean mass gain rates. The proposed lower muscle anabolic properties of SP as opposed to WP sources may be attributed to differences in amino acid composition, especially leucine, and protein digestion and absorption kinetics. Given the small number of articles that compared WP and SP supplementation, additional research is needed to elucidate the physiological effects and differences between whey protein and soy protein supplementation after endurance or resistance exercise.

\section{References}

1. Williamson DL, Kubica N, Kimball SR, Jefferson LS. Exercise $\square$ induced alterations in extracellular signal $\square$ regulated kinase $1 / 2$ and mammalian target of rapamycin (mTOR) signalling to regulatory mechanisms of mRNA translation in mouse muscle. J Physiol 2006;573(2):497-510. doi: 10.1113/jphysiol.2005.103481.

2. Kerksick CM, Rasmussen CJ, Lancaster SL, Magu B, Smith $\mathrm{P}$, Melton C, et al. The effects of protein and amino acid supplementation on performance and training adaptations during ten weeks of resistance training. J Strength Cond Res 2006;20(3):643. doi:10.1519/R-17695.1

3. Elia D, Stadler K, Horváth V, Jakus J. Effect of soy-and whey protein-isolate supplemented diet on the redox parameters of trained mice. Euro J Nutr 2006;45(5):259-66. doi:10.1007/ s00394-006-0593-z.

4. Drummond MJ, Glynn EL, Fry CS, Timmerman KL, Volpi E, Rasmussen BB. An increase in essential amino acid availability upregulates amino acid transporter expression in human skeletal muscle. Am J Physiol-Endocrinol Metabol 2010;298(5):E1011-E8. doi: 10.1152/ajpendo.00690.2009.

5. Tipton KD, Elliott TA, Cree MG, Aarsland AA, Sanford AP, Wolfe RR. Stimulation of net muscle protein synthesis by whey protein ingestion before and after exercise. American 
J Physiol-Endocrinol Metabol 2007;292(1):E71-E76. doi: 10.1152/ajpendo.00166.2006

6. Burke DG, Chilibeck PD, Davidson KS, Candow DG, Farthing J, Smith-Palmer T. The effect of whey protein supplementation with and without creatine monohydrate combined with resistance training on lean tissue mass and muscle strength. Int $\mathrm{J}$ Sport Nutr Exerc Metabol 2001;11(3):349-64.

7. Teixeira KR, Silva ME, Lima WG, Pedrosa ML, Haraguchi FK. Whey protein increases muscle weight gain through inhibition of oxidative effects induced by resistance exercise in rats. Nutr Res 2016;36(10):1081-9. doi: 10.1016/j. nutres.2016.08.003.

8. Thomson RL, Brinkworth GD, Noakes M, Buckley JD. Muscle strength gains during resistance exercise training are attenuated with soy compared with dairy or usual protein intake in older adults: a randomized controlled trial. Clin Nutr 2016;35(1):27-33. doi: 10.1016/j.clnu.2015.01.018.

9. Flik G,Huising M, Gorissen M.Peptides and proteins regulating food intake: a comparative view. Animal Biol 2006;56(4):44773. doi: https://doi.org/10.1163/157075606778967829.

10. Hodgson JM, Croft KD, Puddey IB, Mori TA, Beilin LJ. Soybean isoflavonoids and their metabolic products inhibit in vitro lipoprotein oxidation in serum. J Nutr Biochem 1996;7(12):664-9. doi: https://doi.org/10.1016/S09552863(96)00133-7.

11. Candow DG, Burke NC, Smith-Palmer T, Burke DG. Effect of whey and soy protein supplementation combined with resistance training in young adults. Int J Sport Nutr Exerc Metabol 2006;16(3):233-44.

12. Brown EC, DiSilvestro RA, Babaknia A, Devor ST. Soy versus whey protein bars: effects on exercise training impact on lean body mass and antioxidant status. Nutr J 2004;3(1):22. doi: 10.1186/1475-2891-3-22

13. Kalman D, Feldman S, Martinez M, Krieger DR, Tallon MJ. Effect of protein source and resistance training on body composition and sex hormones. J Int Soc Sports Nutr 2007;4(1):4. doi: 10.1186/1550-2783-4-4.

14. Mobley C, Haun C, Roberson P, Mumford P, Romero M, Kephart WJ, et al. Effects of whey, soy or leucine supplementation with 12 weeks of resistance training on strength, body composition, and skeletal muscle and adipose tissue histological attributes in college-aged males. Nutrients 2017;9(9):972. doi: 10.3390/nu9090972.

15. Volek JS, Volk BM, Gómez AL, Kunces LJ, Kupchak BR, Freidenreich DJ, et al. Whey protein supplementation during resistance training augments lean body mass. JAm College Nutr 2013;32(2):122-35. doi: 10.1080/07315724.2013.793580.

16. Aristizabal JC, Freidenreich DJ, Volk BM, Kupchak BR, Saenz C, Maresh CM, et al. Effect of resistance training on resting metabolic rate and its estimation by a dual-energy X-ray absorptiometry metabolic map. Euro J Clin Nutr 2015;69(7):831. doi: 10.1038/ejen.2014.216.

17. Yang Y, Churchward-Venne TA, Burd NA, Breen L, Tarnopolsky MA, Phillips SM. Myofibrillar protein synthesis following ingestion of soy protein isolate at rest and after resistance exercise in elderly men. Nutr Metabol 2012;9(1):57. doi: 10.1186/1743-7075-9-57.

18. Mitchell CJ, Della Gatta PA, Petersen AC, Cameron-Smith D, Markworth JF. Soy protein ingestion results in less prolonged p70S6 kinase phosphorylation compared to whey protein after resistance exercise in older men. J Int Soc Sports Nutr

\section{5;12(1):6. doi: 10.1186/s12970-015-0070-2.}

19. Tang JE, Moore DR, Kujbida GW, Tarnopolsky MA, Phillips SM. Ingestion of whey hydrolysate, casein, or soy protein isolate: effects on mixed muscle protein synthesis at rest and following resistance exercise in young men. J Appl Physiol 2009;107(3):987-92. doi: 10.1152/japplphysiol.00076.2009.

20. Kanda A, Nakayama K, Sanbongi C, Nagata M, Ikegami $\mathrm{S}$, Itoh $\mathrm{H}$. Effects of whey, caseinate, or milk protein ingestion on muscle protein synthesis after exercise. Nutrients 2016;8(6):339. doi: 10.3390/nu8060339.

21. Anthony TG, McDaniel BJ, Knoll P, Bunpo P, Paul GL, McNurlan MA. Feeding meals containing soy or whey protein after exercise stimulates protein synthesis and translation initiation in the skeletal muscle of male rats. $\mathrm{J}$ Nutr 2007;137(2):357-62. doi: 10.1093/jn/137.2.357.

22. Box W, Hill S, Disilvestro RA. Soy intake plus moderate weight resistance exercise: effects on serum concentrations of lipid peroxides in young adult women. J Sports Med Phys Fitness 2005;45(4):524.

23. Hill S, Box W, Disilvestro RA. Moderate intensity resistance exercise, plus or minus soy intake: effects on serum lipid peroxides in young adult males. Int $\mathrm{J}$ Sport Nutr Exerc Metabol 2004;14(2):125-32.

24. Spiering BA, Kraemer WJ, Anderson JM, Armstrong LE, Nindl BC, Volek JS, et al. Resistance exercise biology: manipulation of resistance exercise programme variables determines the responses of cellular and molecular signalling pathways. Sports Med 2008;38(7):527-40. doi: 10.2165/00007256-200838070-00001.

25. Atherton PJ, Smith K. Muscle protein synthesis in response to nutrition and exercise. J Physiol 2012;590(5):1049-57. doi: 10.1113/jphysiol.2011.225003.

26. Reynolds TH, Bodine SC, Lawrence JC. Control of Ser2448 phosphorylation in the mammalian target of rapamycin by insulin and skeletal muscle load. J Biol Chem 2002;277(20):17657-62. doi: 10.1074/jbc.M201142200.

27. Phillips SM, Hartman JW, Wilkinson SB. Dietary protein to support anabolism with resistance exercise in young men. J Am College Nutr 2005;24(2):134S-9S.

28. Mcglory C, Devries MC, Phillips SM. Skeletal muscle and resistance exercise training; the role of protein synthesis in recovery and remodeling. J. Appl Physiol 2016;122(3):541-8. doi: 10.1152/japplphysiol.00613.2016.

29. Kumar V, Atherton PJ, Selby A, Rankin D, Williams J, Smith $\mathrm{K}$, et al. Muscle protein synthetic responses to exercise: effects of age, volume, and intensity. J Gerontol 2012;67(11):1170-7. doi: $10.1093 /$ gerona/gls141.

30. Butteiger DN, Cope M, Liu P, Mukherjea R, Volpi E, Rasmussen BB, et al. A soy, whey and caseinate blend extends postprandial skeletal muscle protein synthesis in rats. Clin Nutr 2013;32(4):585-91. doi: 10.1016/j.clnu.2012.10.001.

31. Van Vliet S, Burd NA, Van Loon LJC. The skeletal muscle anabolic response to plant-versus animal-based protein consumption. J Nutr 2015;145(9):1981-91. doi: 10.3945/ jn.114.204305.

32. Tang JE, Phillips SM. Maximizing muscle protein anabolism: the role of protein quality. Curr Opin Clin Nutr Metab Care 2009;12(1):66-71. doi: 10.1097/MCO.0b013e32831cef75.

33. Anthony JC, Anthony TG, Layman DK. Leucine supplementation enhances skeletal muscle recovery in rats following exercise. J Nutr 1999;129(6):1102-6. doi:10.1093/ 


$$
\text { jn/129.6.1102 }
$$

34. Lane MT, Herda TJ, Fry AC, Cooper MA, Andre MJ, Gallagher PM. Endocrine responses and acute mTOR pathway phosphorylation to resistance exercise with leucine and whey. Biol Sport 2017;34(2):197. doi: 10.5114/ biolsport.2017.65339

35. Lollo PCB, Silva LBC, Batista TM, Morato PN, Moura $\mathrm{CS}, \mathrm{Cruz} \mathrm{AG}$, et al. Effects of whey protein and casein plus leucine on diaphragm the mTOR pathway of sedentary, trained rats. Food Res Int 2012;49(1):416-24. doi:10.1016/j. foodres.2012.07.024

36. Bos C, Metges CC, Gaudichon C, Petzke KJ, Pueyo $\mathrm{ME}$, Morens $\mathrm{C}$, et al. Postprandial kinetics of dietary amino acids are the main determinant of their metabolism after soy or milk protein ingestion in humans. J Nutr 2003;133(5):130815. doi: $10.1093 /$ jn/133.5.1308

37. Tipton KD, Ferrando AA, Phillips SM, Doyle Junior D, Wolfe RR. Postexercise net protein synthesis in human muscle from orally administered amino acids. Am J Physiol-
Endocrinol Metabol 1999;276(4):E628-E34. doi:10.1152/ ajpendo.1999.276.4.E628.

38. Disilvestro RA, Nutrition H. Antioxidant actions of soya. Leatherhead Food RA Food Ind J 2001;4:210-20.

39. Liu J, Chang SKC, Wiesenborn D. Antioxidant properties of soybean isoflavone extract and tofu in vitro and in vivo. J Agric Food Chem 2005;53(6):2333-40. doi:10.1021/ jf048552e

40. Erba D, Casiraghi MC, Martinez-Conesa C, Goi G, Massaccesi L. Isoflavone supplementation reduces DNA oxidative damage and increases $\mathrm{O}-\beta-\mathrm{N}$-acetyl-D-glucosaminidase activity in healthy women. Nutr Res 2012;32(4):233-40. doi: 10.1016/j.nutres.2012.03.007.

41. Yoon G, Park S. Antioxidant action of soy isoflavones on oxidative stress and antioxidant enzyme activities in exercised rats. Nutr Res Pract 2014;8(6):618-24. doi: 10.4162/nrp.2014.8.6.618. 